POLYCHLORINATED BIPHENYL CONCENTRATIONS IN

HUDSON RIVER WATER AND TREATED DRINKING WATER

AT WATERFORD, NEW YORK

By Roy A. Schroeder and Charles R. Barnes

U.S. GEOLOGICAL SURVEY

Water-Resources Investigations Report 83-4188

Prepared in cooperation with the

BOARD OF WATER COMMISSIONERS OF

THE TOWN OF WATERFORD and

NEW YORK STATE DEPARTMENT OF

ENVIRONMENTAL CONSERVATION

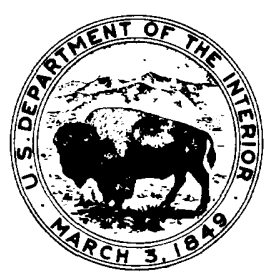

Albany, New York 
UNITED STATES DEPARTMENT OF THE INTERIOR

JAMES G. WATT, Secretary

GEOLOGICAL SURVEY

Dallas L. Peck, Director

For additional information write to:

U.S. Geological Survey

P.0. Box 1350

Albany, New York 12201

(518) 472-3107
Copies of this report may be purchased from:

Open-File Services Section Western Distribution Branch U.S. Geological Survey Box 25245, Denver Federal Center Denver, Colo. 80225

(303) 234-5888 


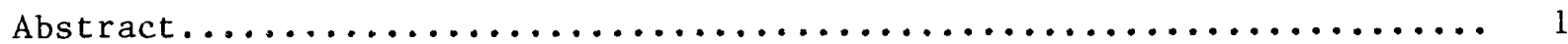

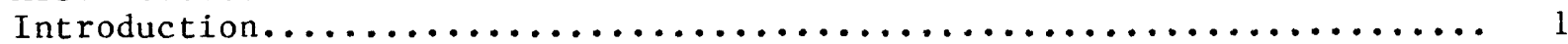

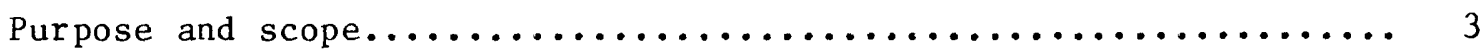

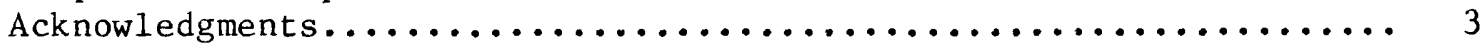

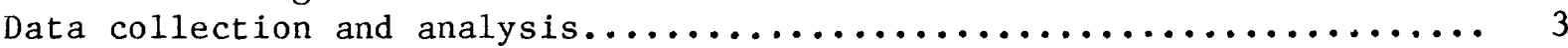

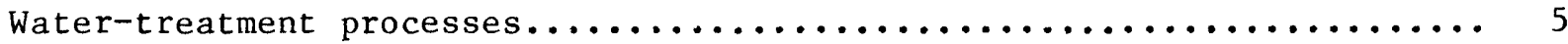

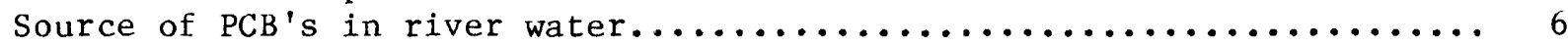

Results and discussion............................... 8

Comparison between raw-water-tap samples and river samples...... 8

PCB concentration after treatment...................... 9

Heavy-metals removal during treatment..................... 11

Comparison with other treatment processes................. 11

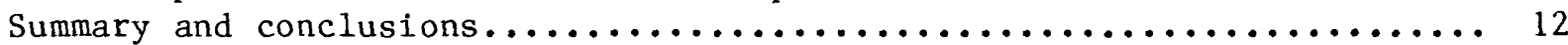

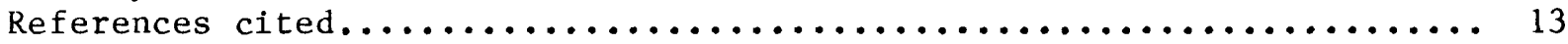

\section{ILLUSTRATIONS}

Figure 1.--Map showing upper Hudson River basin and location of reach from Hudson Falls to Waterford................ 2

2.--Map showing major geographic features of Waterford area..... 4

3.--Graph showing relationship between dissolved and total recoverable $\mathrm{PCB}$ 's in Hudson River at Waterford........ 7

Figure 4.--Graphs showing relationship between $\mathrm{PCB}$ concentrations in treated and untreated water at Waterford treatment

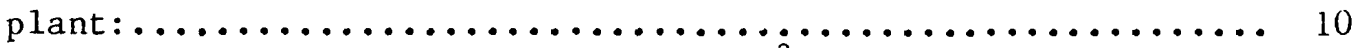
$A$, at river discharge less than $600 \mathrm{~m}^{3} / \mathrm{s}$ $B$, at river discharge greater than $600 \mathrm{~m}^{3} / \mathrm{s}$

\section{TABLES}

Table 1.--Annual distribution of mean daily discharge of Hudson River at Waterford, $1977-81 \ldots \ldots \ldots \ldots \ldots \ldots \ldots \ldots \ldots \ldots$

2.--Concentrations of selected constituents in samples from raw-water tap in Waterford treatment plant and from Hudson River at Route 4 bridge. 


\section{CONVERSION FACTORS AND ABBREVIATIONS}

The following factors may be used to convert International System of Units (SI) to inch-pound units of measurement.

Multiply SI units

kilometer $(\mathrm{km})$

cubic meter per second $\left(\mathrm{m}^{3} / \mathrm{s}\right)$

cubic meter per day $\left(\mathrm{m}^{3} / \mathrm{d}\right)$ by

0.6214

35.31

$2.642 \times 10^{-4}$
To obtain inch-pound units

mile (mi)

cubic foot per second $\left(\mathrm{ft}^{3} / \mathrm{s}\right)$

million gallons per day (Mgal/d)

Other abbreviations used in the text of this report include:

$\mathrm{mg} / \mathrm{L}$, milligram per liter

$\mu \mathrm{S} / \mathrm{cm}$, microsiemen per centimeter

$\mu \mathrm{g} / \mathrm{L}$, microgram per liter

$\mu \mathrm{g} / \mathrm{g}$, microgram per gram 


\title{
Polychlorinated Biphenyl Concentrations in Hudson River Water and Treated Water at Waterford, New York
}

\author{
By Roy A. Schroeder and Charles R. Barnes
}

\begin{abstract}
Past discharge of $P C B^{\prime} s$ into the Hudson River has resulted in contaminant concentrations of a few tenths of a microgram per liter in the water. Waterford is one of two large minicipal users of the Hudson River for drinking-water supply. The treatment scheme at the Waterford plant, which processes approximately 3,800 cubic meters per day, is similar to that of most conventional treatment plants except for the addition of powdered activated carbon during flocculation. Comparison of $P C B$ concentrations in river water and intake water at the plant with concentrations in treated drinking-water samples indicates that purification processes remove 80 to 90 percent of the $P C B^{\prime} s$ and that final concentrations seldom exceeded 0.1 microgram per liter. No significant difference was noted between the removal efficiencies during periods of high miver discharge, when PCB's are associated with suspended sediment, and at low discharge, when PCB's are generally dissolved.
\end{abstract}

\section{INTRODUCTION}

Discharge of polychlorinated biphenyls ( $\mathrm{PCB}$ 's) from two industrial outfalls $1 \mathrm{~km}$ apart at Fort Edward and Hudson Falls, N.Y., from 1950 to the mid-1970's has caused serious degradation of water quality of the Hudson River. Although discharge from these point sources was greatly reduced in the mid-1970's and finally terminated in 1977, sediment and water in the entire $300-\mathrm{km}$ reach downstream from the outfalls remain contaminated (Tofflemire and Quinn, 1979). The highest concentration of PCB's in bottom sediments is in the 20-km reach between Hudson Falls and Schuylerville (fig. 1). These highly contaminated sediments now serve as the major source of $\mathrm{PCB}^{\prime} \mathrm{s}$ in Hudson River water downstream (Schroeder and Barnes, 1983).

Systematic monitoring of $\mathrm{PCB}$ concentrations in Hudson River water at Waterford was begun by the U.S. Geological Survey in late 1975. Monitoring was subsequently extended to include additional sites on the Hudson River as part of a broad assessment of PCB's in the river (Turk, 1980; Turk and Troutman, $1981 \mathrm{~b}$, and Schroeder and Barnes, 1983). The principal objectives of the studies cited above were to (1) determine the relationship between PCB concentration and river discharge, (2) estimate waterborne PCB transport rates, and ( 3 ) discern trends in the level of contamination.

Waterford is one of two municipalities that obtain their drinking-water supply from the Huds on River. 


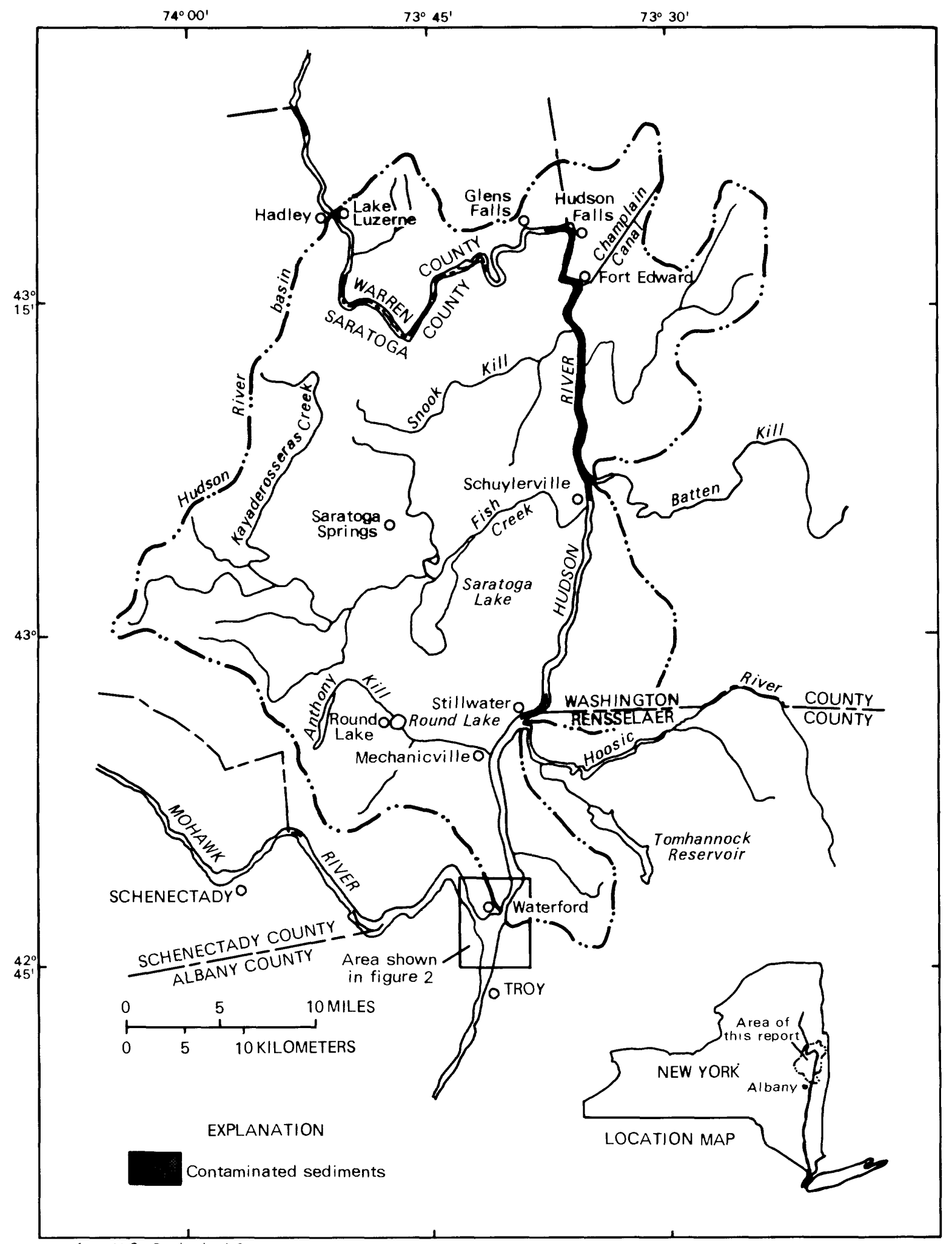

Base from U.S. Geological Survey

State base map, 1974

Figure 1.--Upper Hudson River basin and location of reach from Hudson Falls to Waterford. Detail of Waterford area is given in figure 2 . 


\section{Purpose and Scope}

This study was undertaken to evaluate the reduction in PCB concentrations in Hudson River water that occurs during treatment at the Waterford plant. The concentration of PCB's in untreated Hudson River water were compared with those in treated drinking water at Waterford, and an average removal efficiency at the treatment plant was calculated. Removal efficiency was calculated for periods of high flow, when PCB's are associated principally with suspended sediment, and for periods of lower flow, when PCB's are predominantly dissolved. Comparison was also made for a few selected heavy metals (mainly iron) from available data.

\section{Acknowledgments}

Data were collected and interpreted under projects done in cooperation with the Board of Water Commissioners of the Town of Waterford, N.Y., and the New York State Department of Environmental Conservation. We thank Harold Berger, Waterford water-treatment-plant manager, for his assistance.

\section{DATA COLLECTION AND ANALYSIS}

Data were collected from late 1975 through 1981. Complete descriptions of field and laboratory methods are given in Turk and Troutman (1981a, 1981b) and Schroeder and Barnes (1983). Samples for analysis of untreated ( $r a w$ ) water were taken at two locations--from a bridge spanning the Hudson River on U.S. Highway $4,0.6 \mathrm{~km}$ upstream from the northernmost branch of the Mohawk River, and from a raw-water tap in the treatment plant (fig. 2). The rawwater intake for the treatment plant is $0.5 \mathrm{~km}$ upstream from the bridge. Samples for analysis of treated water were taken from a treated-water tap in the Waterford municipal water-treatment plant.

All PCB analyses were done by the U.S. Geological Survey's National Water-Quality Laboratory in Doraville, Ga., on a gas chromatograph (GC). The GC was calibrated by injecting a standard mixture of PCB's. Detection limit for PCB concentrations in raw water was about $0.02 \mu \mathrm{g} / \mathrm{L}$.

Polychlorinated biphenyls are not a single compound but a chemical family of many individual congeners with a basic structural similarity. Congeneric differences are noted by the number and position of chlorine atoms on the biphenyl molecule. Quantification of results for treated water was somewhat difficult because of the generally low concentrations in the samples and the dissimilarities between $\mathrm{PCB}$ composition in river-water samples and laboratory standards. These dissimilarities may be due to processes in the river, such 


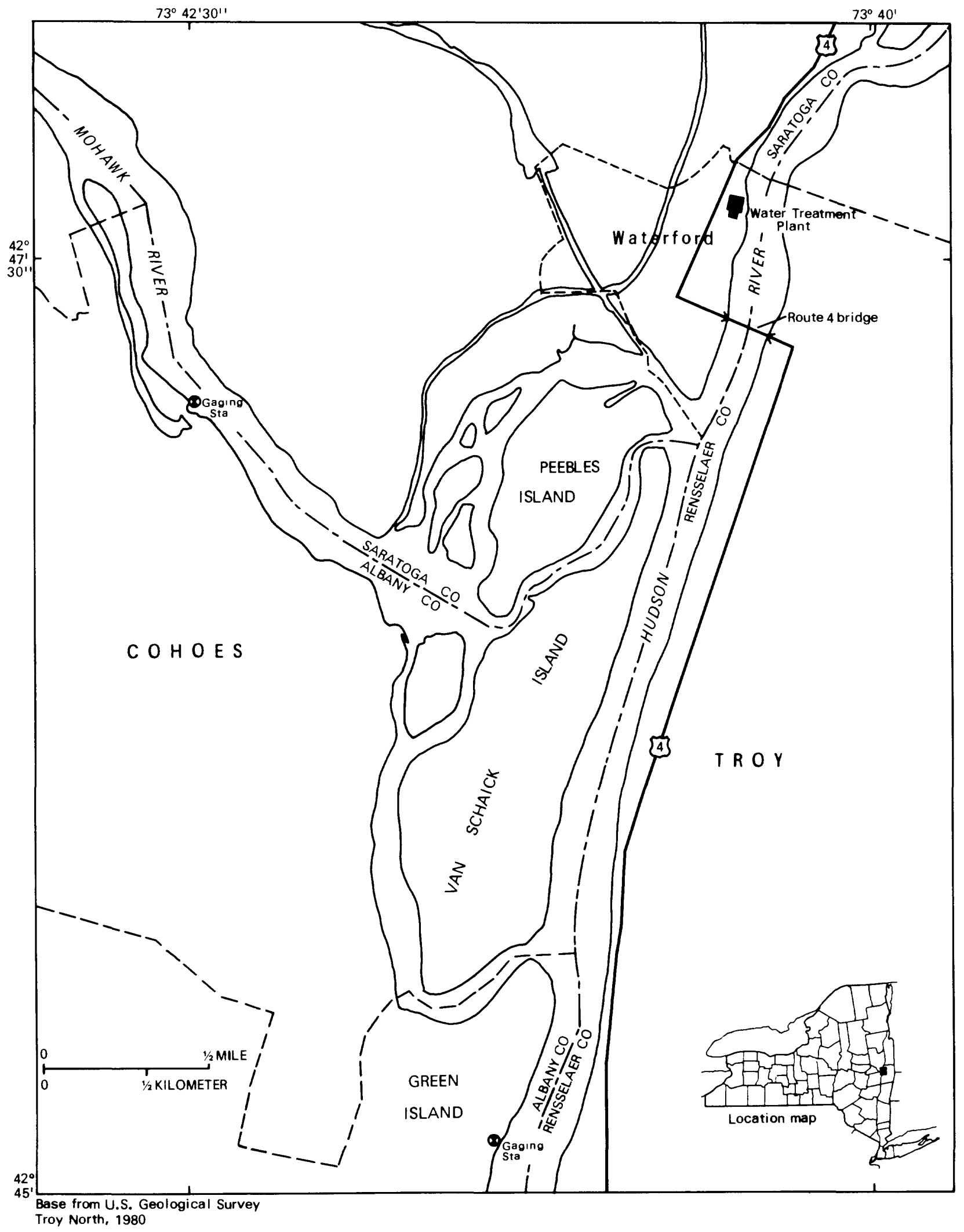

Figure 2.--Major geographic features of Waterford area. (Location is shown in figure 1.) 
as mixing of various Aroclors ${ }^{l}$, environmental fractionation, biologically induced chemical changes, or preferential removal of the more chlorinated congeners by treatment processes (Konda and others, 1974). When evidence for PCB congeners was lacking, that is, no peaks other than a few immediately after the injection peak appeared on the gas-chromatographic trace, the concentration was designated as zero.

All metal analyses also were done by the U.S. Geological Survey Laboratory in Doraville, Ga., by atomic absorption spectrophotometry.

\section{WATER-TREATMENT PROCESSES}

The Waterford drinking-water-treatment plant processes an average of $3,800 \mathrm{~m}^{3} / \mathrm{d}$ by methods commonly used for treatment of surface waters. The following description of the treatment process is based on discussions with the plant manager (H. Berger, oral commun., 1981-82) and on site visits.

Intake screens prevent large riverborne materials from entering the facility. During extremely high flows, suspended sediment causes the rapid clogging of intake screens, reducing inflow and necessitating the purchase of water from the city of Troy, which obtains its water from the Tomhannock Reservoir (fig. 1).

The water is aerated before treatment. Colloidal and larger particles are removed by coagulation and chemical precipitation followed by filtration. In the coagulation step, intake water is mixed rapidly with liquid alum $\left[\mathrm{Al}_{2}\left(\mathrm{SO}_{4}\right)_{3} \cdot 18 \mathrm{H}_{2} \mathrm{O}\right]$, activated silica, and sodium bicarbonate. The alum coagulant produces an adsorbent, insoluble aluminum hydroxide flocculant. Activated silica aids coagulation by accelerating formation and improving the physical characteristics of the flocculant. Sodium bicarbonate ensures sufficient alkalinity to maintain the $\mathrm{pH}$ necessary for flocculant formation.

The water is mixed slowly, during which time the flocculant traps particles and colloids and adsorbs some soluble substances. Since 1958, powdered activated carbon has been added during flocculation to adsorb dissolved organic compounds. The flocculants adhere to one another, thereby increasing in size. Larger particles and flocculants are allowed to settle out in sedimentation basins. Small particles that do not settle out are removed by rapid sand filtration. In 1976 all filters were dual media--sand plus anthracite; subsequently some of the filters were converted to a single medium (sand).

Final steps before distribution of the treated water include chlorination and adjustment of $\mathrm{pH}$.

1 Use of brand names is for identification purposes only. 


\section{SOURCE OF PCB'S IN RIVER WATER}

As previously noted, highly contaminated sediments are the current source of PCB's in the Hudson River. Mean annual concentrations of PCB's in the Hudson River at Waterford were highest during the 1976 water year, with an annual value of $0.51 \mathrm{\mu g} / \mathrm{L}$. Between 1977 and 1979 , the mean ranged from 0.35 to $0.39 \mu \mathrm{g} / \mathrm{L}$. The annual mean PCB concentration declined to $0.25 \mu \mathrm{g} / \mathrm{L}$ in 1980 and to $0.19 \mu \mathrm{g} / \mathrm{L}$ in 1981 .

Studies have shown that during a given year, $\mathrm{PCB}$ concentrations in Hudson River water at Waterford, as well as sites upstream, are minimal at intermediate water discharge $\left(200\right.$ to $\left.600 \mathrm{~m}^{3} / \mathrm{s}\right)$ and increase at discharges above or below this range (Turk, 1980; Turk and Troutman, 1981b; Schroeder and Barnes, 1983). This relationship results from a combination of two mechanisms by which PCB's migrate from the riverbed to the overlying water. During high flows (discharges greater than $600 \mathrm{~m}^{3} / \mathrm{s}$ ), scouring and resuspension of bottom material is the dominant mechanism, and as discharge increases beyond this value, both $\mathrm{PCB}$ and suspended-sediment concentrations increase. Most high flows are generated by spring snowmelt and occur only during about 2.5 weeks of a typical year. However, large differences from year to year are possible (table 1 ).

If resuspension were the only source of $\mathrm{PCB}$ 's, concentration would decrease below the detection limit as discharge and suspended-sediment concentrations decrease. However, PCBs are also continually desorbed from bottom sediments at a more or less constant rate. Schroeder and Barnes (1983) calculated this rate at Waterford annually between 1976 and 1981 . Although the rate is decreasing with time, it may be considered fixed during any given

\section{Table 1.--Annual distribution of daily mean discharges of Hudson River at Waterford, 1977-81.}

\begin{tabular}{|c|c|c|c|c|c|c|c|}
\hline \multirow{2}{*}{$\begin{array}{c}\text { Flow range } \\
\left(\mathrm{m}^{3} / \mathrm{s}\right)\end{array}$} & \multicolumn{4}{|c|}{$\begin{array}{r}\text { Number of days in stated } \\
\text { during water year } \\
\end{array}$} & & \multicolumn{2}{|c|}{$\begin{array}{l}\text { Percentage of days } \\
\text { in stated range }\end{array}$} \\
\hline & 1977 & 1978 & 1979 & 1980 & 1981 & observed & expected ${ }^{2}$ \\
\hline Greater than 600 & 28 & 13 & 29 & 6 & 7 & 4.5 & 4.5 \\
\hline Greater than 453 & 51 & 62 & 52 & 14 & 13 & 10.5 & 10.0 \\
\hline 200 to 600 & 155 & 215 & 116 & 110 & 80 & 37.0 & 34.5 \\
\hline Less than 200 & 182 & 137 & 220 & 250 & 278 & 58.5 & 61.0 \\
\hline Less than 77 & 20 & 31 & 22 & 38 & 54 & 9.0 & 10.0 \\
\hline
\end{tabular}

1 Water year is the 12-month period from 0ctober 1 of the previous calender year to September 30 .

2 Based on estimated flow-duration curve developed from 20 years of record obtained from Hudson River at Green Island and Mohawk River at Cohoes discharge gages. 
year. As a result of this nearly uniform desorption, PCB concentrations in river water increase as discharge decreases below $200 \mathrm{~m} / \mathrm{s}$ because the amount of dilution is lessened.

One consequence of this dual mechanism is that during high flows, riverborne $P C B$ 's are associated principally with suspended sediment, whereas at lesser flows they are predominantly dissolved ${ }^{1}$. A comparison between total recoverable and dissolved $\mathrm{PCB}$ concentrations in the Hudson River at the Waterford bridge is given in figure 3. Schroeder and Barnes (1983) report that during high flows, 90 percent of the total recoverable PCB's are associated with the suspended fraction, whereas during lower flows, only 20 percent are on suspended particles, and 80 percent are dissolved.

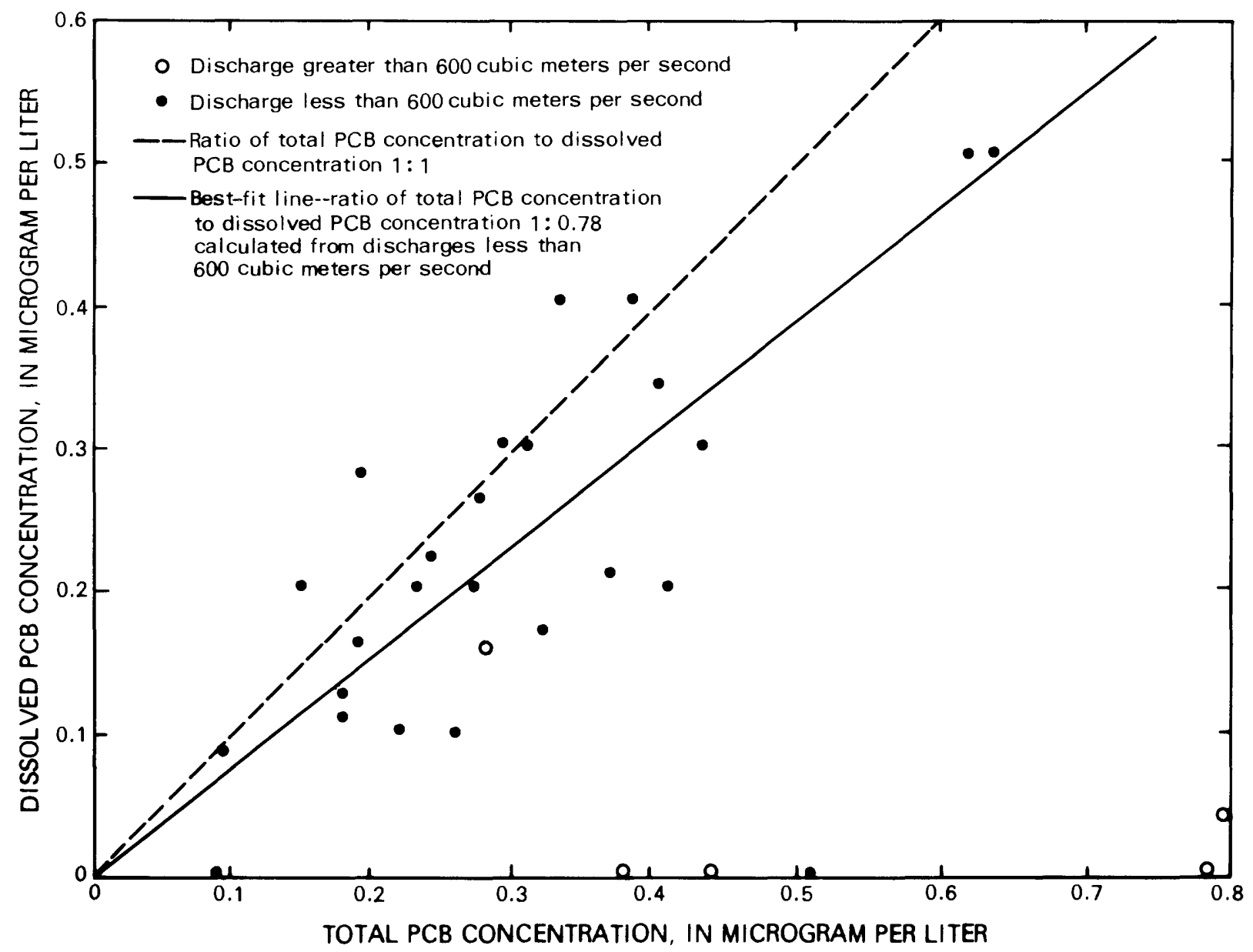

Figure 3.--Relationship between dissolved and total recoverable $P C B$ concentrations in Hudson River at Waterford.

1 Dissolved refers to that material in a sample which passes through a $0.45-\mu \mathrm{m}$ silver oxide filter. 


\section{RESULTS AND DISCUSSION}

To calculate the overall efficiency of $\mathrm{PCB}$ removal at the Waterford treatment plant, the concentration of total recoverable PCB's in water was compared before and after treatment. Most samples collected for comparison of treated and untreated water were taken during intermediate and low flows, especially during summer, when low discharges result in high concentrations of dissolved PCB's in the river water. This sampling bias was chosen in part because flows less than $200 \mathrm{~m}^{3} / \mathrm{s}$ normally occur during more than half the year (table 1) and because alternate sources of water are used during extremely high discharge. It also seems likely that treatment would be less effective in removing the dissolved fraction than the suspended fraction. Calculated removal efficiencies during low-flow conditions, therefore, should represent "worst-case" values.

\section{Comparison between Raw-Water-Tap Supplies and River Samples}

Because untreated water samples had previously been collected either from the raw-water tap at the Waterford treatment plant or from the Route 4 bridge, several samples were collected simultaneously at both locations during this study. The comparison of water at the bridge with water from the plant intake was expected to reveal no detectable difference but would increase the number of sample pairs available for calculation of PCB removal efficiency in the plant.

The principal source of $\mathrm{PCB}^{\prime} \mathrm{s}$ is contaminated sediment 30 to $50 \mathrm{~km}$ upstream (Schroeder and Barnes, 1983), from which the Hudson River water's traveltime to Waterford ranges from about $1 / 2$ to 3 days, depending on flow. That distance, and the absence of large tributaries directly upstream, should result in thorough mixing of the river at Waterford. Measurements of specific conductance and suspended-sediment concentrations across the river's width at the Waterford bridge confirmed complete mixing of major dissolved ions and suspended constituents at this location (J. T. Turk, U.S. Geological Survey, written commun., 1979). Hence, sampling at virtually any reasonable location in the river near Waterford, including the intake pipe, should result in water of representative chemical composition.

During the summer of 1981 , seven samples from a fixed location near the center of flow of the Hudson River at the Waterford bridge were collected concurrently with samples from the raw-water tap at the Waterford plant. The samples were analyzed for total recoverable iron, manganese, chromium, PCB's, and specific conductance. The absolute percentage difference in concentration between each of the seven pairs was tabulated and used to calculate the mean difference between the two sites (table 2). This difference is less than analytical precision for the inorganic constituents (Skougstad and others, 1979) and approximately equal to precision for PCB's (Schroeder and Barnes, 1983).

Although samples used in the comparison above were obtained during relatively constant low flows, the conclusions reached are probably valid for higher flows as well. Total concentrations of recoverable heavy metals at 
Waterford have been found to be proportional to the suspended-sediment concentration when river discharge exceeds $620 \mathrm{~m} 3 / \mathrm{s}$ (Turk and Troutman, 1981a). During intermediate or low flows, however, metals concentrations cannot be predicted from suspended-sediment concentration by extrapolation of the regression relationship between these variables. Although no data on dissolved concentrations of these constituents at either the treatment plant or bridge are available, a NASQAN (National Stream Quality Accounting Network) gaging station $4 \mathrm{~km}$ downstream at Green Island (fig. 2) provides an adequate record. Data from this site indicate that a substantial fraction of heavy metals is associated with suspended material, even at low flow (U.S. Geological Survey, 1977-82).

Table 2.--Concentrations of selected constituents in samples from raw-water tap in Waterford treatment plant and from Hudson River at the Route 4 bridge.

[Mean concentrations are based on seven paired samples collected in 1981; difference is the average difference between each of the seven pairs.]

\begin{tabular}{|c|c|c|c|c|c|}
\hline \multirow[b]{3}{*}{ Constituent } & \multicolumn{4}{|c|}{ Concentration $(\mu \mathrm{g} / \mathrm{L})$} & \multirow{3}{*}{$\begin{array}{c}\text { Mean } \\
\text { difference } \\
\text { (percent) }\end{array}$} \\
\hline & \multicolumn{2}{|c|}{ Raw-water tap } & \multicolumn{2}{|c|}{ Bridge } & \\
\hline & mean & range & mean & range & \\
\hline Chromium & 16 & $7-24$ & 15 & $7-19$ & 7.4 \\
\hline Iron & 224 & $190-350$ & 256 & $199-410$ & 15 \\
\hline Manganese & 30 & $20-50$ & 26 & $20-30$ & 18 \\
\hline PCB's & 0.12 & $0.05-0.24$ & 0.10 & $0.05-0.17$ & 18 \\
\hline Specific conductance* & 146 & $133-164$ & 144 & $133-164$ & 1.6 \\
\hline
\end{tabular}

* Specific conductance reported as microsiemens per centimeter at $25^{\circ} \mathrm{C}$.

\section{PCB Concentrations After Treatment}

Results of $\mathrm{PCB}$ analysis of treated and untreated water at Waterford at discharges less than $600 \mathrm{~m}^{3} / \mathrm{s}$ are shown in figure $4 \mathrm{~A}$; those at discharges greater than $600 \mathrm{~m}^{3} / \mathrm{s}$ are shown in figure $4 \mathrm{~B}$. In the few cases where untreated samples were available from both the bridge and raw-water tap, average values from the two samples are plotted. 
Concentration-weighted average efficiency of $\mathrm{PCB}$ removal was 87 percent during high flows for the entire study. Before October 1976, removal efficiency during lesser flows had been 65 percent but was 88 percent thereafter. No reason for this improvement after 1976 is known. Discharge of PCB's to the river was still occurring during 1976, and, even though the quantity was negligible compared to riverborne transport rate during high flows, the concentration during low flow could have been significant (Schroeder and Barnes, 1983). The increase in removal efficiency can probably not be attributed to changes in physical-chemical form of $P C C^{\prime} s$ in river water during or after effluent discharge ceased because rates of adsorption-desorption reactions on particles are more than 10 times faster than traveltime from the outfalls to Waterford (Brown, 1981). The difference may reflect lesser chlorinated congeners present in the water during the period of $\mathrm{PCB}$ discharge. These lesser chlorinated PCB's are generally more difficult to remove by carbon adsorption.

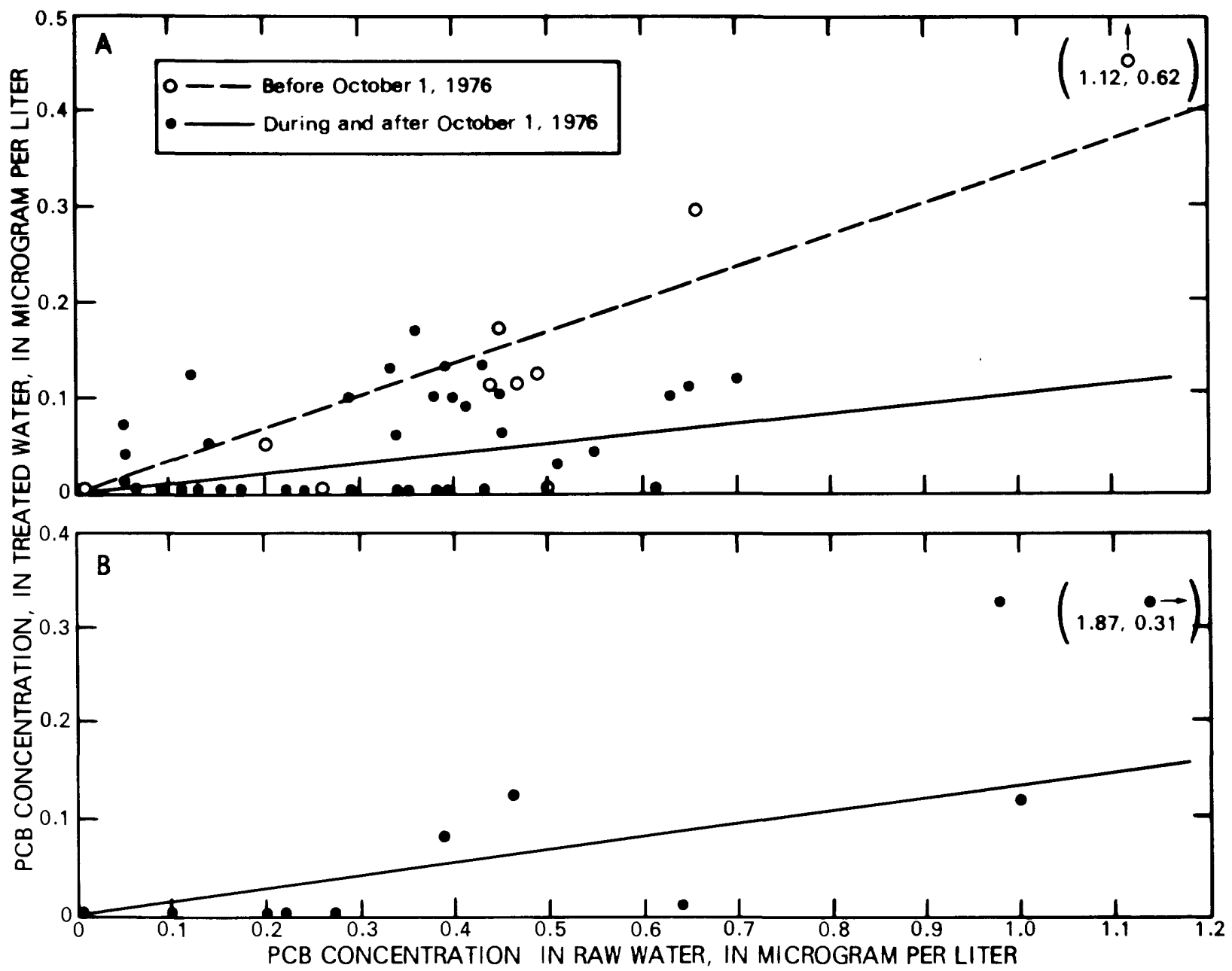

Figure 4.--Relationship between $P C B$ concentrations in treated and untreated water at Waterford treatment plant. $A$, at discharges less than $600 \mathrm{~m}^{3} / \mathrm{s} ; B$, at discharges greater than $600 \mathrm{~m}^{3} / \mathrm{s}$. 
Statutes defining allowable limits for $P C B$ 's in drinking water have not been established. Brinkman and others (1980) state the estimated additional cancer risk to a person drinking water throughout his life to be $10^{-6}$ for a $\mathrm{PCB}$ concentration of $0.16 \mathrm{\mu g} / \mathrm{L}$. On the basis of results in this report, that level would typically be exceeded in Waterford's drinking water only when concentrations in the Hudson River approach or exceed $1 \mu \mathrm{g} / \mathrm{L}$. Such levels were present in only a small percentage of the samples collected during this study, and, with the recent decrease in $\mathrm{PCB}$ concentrations in the river (Schroeder and Barnes, 1983), they can be expected to occur on only a few days each year. Compared to the normal cancer incidence of $10^{-1}$, the incremental risk from exposure to drinking water at Waterford would seem to be undetectably small.

As additional information becomes available on the health risks of PCB's, and as PCB concentrations in the Hudson River continue to change with time, data on the efficiency of removal at the Waterford treatment plant can be used to estimate historical and future levels of exposure by the local populace.

\section{Heavy Metals Removal During Treatment}

Analyses of total recoverable iron in untreated and treated water are available from summer low flows in 1978 and 1979. Average removal efficiency is calculated to be 85 percent. Data from Green Island, $4 \mathrm{~km}$ downstream from Waterford, suggest that iron is predominantly suspended, but during low flows the dissolved fraction may be as much as 20 percent (U.S. Geological Survey, 1977-82).

Two sample pairs collected during the summer of 1981 indicate that manganese and lead ${ }^{l}$ also are removed during treatment, although their removal is less effective than that of iron. After treatment, chromium and nickel concentrations increased slightly, and copper concentrations doubled. The system's failure to remove these elements could reflect accumulation from within the plant's distribution system because concentrations of trace metals (excluding iron) were only about $10 \mathrm{\mu g} / \mathrm{L}$ in the untreated water. The concentrations of chromium, nickel, and copper after treatment were still far below the limits for drinking water (U.S. Environmental Protection Agency, 1977).

\section{Comparison with Other Treatment Processes}

No attempt was made to determine which steps in the treatment process at Waterford were responsible for removal of PCB's from the water. However, plausible suggestions can be made on the basis of evidence obtained from laboratory simulations and data from other plants. Stone and others (1975) evaluated several processes for removal of numerous chemical constituents in water. They concluded that while alum coagulation removes substantial fractions of many organic chemicals, including chlorinated insecticides, removal efficiency decreases sharply at low concentrations such as those of PCB's at Waterford.

1 Average removal efficiency for lead was measured at 50 percent from 1977-79 but had a large variation of unknown cause. 
Analysis of solids in the settling basins at Waterford revealed PCB concentrations of 0.4 to $4 \mathrm{\mu g} / \mathrm{g}$. These values are somewhat less than the PCB concentrations in bottom sediment at Waterford (Turk and Troutman, 1981 b) and on suspended sediment (Turk and Troutman, 1981b; Schroeder and Barnes, 1983) at Waterford. Lower values may reflect dilution by alum, although the absence of data required for mass balances at various steps in treatment renders this conclusion only tentative.

A comparison of $P C B$ 's in treated and untreated water at Fort Edward provides a clue as to which step in treatment may be most responsible for PCB removal. Although the village of Fort Edward does not use the Hudson River as a water supply, it does use nearby reservoirs that contain measurable concentrations of PCB's. Brinkman and others (1980) report that mean concentrations in 1978 were $0.113 \mathrm{\mu g} / \mathrm{L}$ in the impounded water and $0.085 \mu \mathrm{g} / \mathrm{L}$ in the drinking water, with no statistical significance in the difference between them. The most obvious difference between treatment processes at Waterford and Fort Edward is the addition of powdered activated carbon during flocculation at Waterford. Activated carbon is an effective adsorbent for hydrophobic organic compounds, which suggests that this step may be responsible for removal of dissolved PCB's. Suspended PCB's are probably removed simply by coagulation and settling.

\section{SUMMARY AND CONCLUSIONS}

Discharge of PCB's from two industrial outfalls from 1950 to 1977 has seriously degraded the water quality of the Hudson River. Although discharges were terminated in 1977, the heavily contaminated sediments in a $20-\mathrm{km}$ reach downstream from the outfalls serves as a major source of PCB's in the river water. Two mechanisms control the concentration of PCB's in the Hudson River; at high flows (greater than $600 \mathrm{~m}^{3} / \mathrm{s}$ ), scouring and resuspension predominate, whereas at lower flows, desorption of $\mathrm{PCB}$ 's from sediments predominates.

Mean annual PCB concentrations in the Hudson River at Waterford, $50 \mathrm{~km}$ below the outfa1ls, have declined from $0.51 \mathrm{\mu g} / \mathrm{L}$ in 1976 to $0.19 \mu \mathrm{g} / \mathrm{L}$ in 1981 . Waterford is one of two municipalities that use the river as a source of drinking water.

The water-treatment methods used at the Waterford facility, which processes approximately $3,800 \mathrm{~m}^{3} / \mathrm{d}$, are similar to those used at most conventional treatment plants. The major difference is the addition of powdered activated carbon during flocculation. Comparison of PCB concentrations in untreated water from both the river and the plant's raw-water tap with treated water from the plant indicates that the processes used to purify the water remove almost 90 percent of the PCB's. During high flows, the concentrationweighted average removal efficiency was 87 percent. Coagulation and sedimentation are probably the most important phases of treatment for PCB removal during high flows, when PCB's are associated with suspended particulates. At lesser flows, when PCB's are mostly in the dissolved state, the removal efficiency since October 1976 has been 88 percent. The removal of PCB's during these lesser flows is attributed to the addition of powdered activated carbon.

Because PCB concentrations in the Hudson River at Waterford are almost always less than $1 \mu \mathrm{g} / \mathrm{L}$ and seem to be decreasing with time, concentrations in the treated drinking water are usually less than $0.1 \mathrm{\mu g} / \mathrm{L}$. 


\section{REFERENCES CITED}

Brinkman, M., Fogelman, K., Hoeflein, J., Lindh, T., Patel, M., Trench, W. C., and Aikens, D. A., 1980, Distribution of polychlorinated biphenyls in the Fort Edward, New York, water system: Environmental Management, v. 4, p. 511-520.

Brown, M. P., 1981, PCB desorption from river sediments suspended during dredging--an analytical framework: New York State Department of Environmental Conservation Technical Paper 65, 28 p.

Konda, M., Kishi, T., Shimamato, T., Nishihara, T., and Watabe, K., 1974 , Studies on the adsorptive effect of activated charcoal on polychlorinated biphenyls in water: Oshaka, Japan, Memoirs of the Faculty of Pharmaceutical Sciences, v. 18, p. 135-138.

Schroeder, R. A., and Barnes, C. R., 1983, Trends in polychlorinated biphenyl concentrations in Hudson River waters five years after elimination of point sources in 1976: U.S. Geological Survey Water-Resources Investigations Report 83-4206, 28 p.

Skougstad, M. W., Fishman, M. J., Friedman, L. C., Erdmann, D. E., and Duncan, S. S. (eds.), 1979, Methods for determination of inorganic substances in water and fluvial sediments: U.S. Geological Survey Techniques of Water-Resources Investigations, Book 5, Chapter Al.

Stone, R., Smallwood, H. A., and Marsh, J. R., 1975, Treatment effectiveness for the removal of selected contaminants from drinking water: U.S. Envi ronmental Protection Agency, 183 p.

Tofflemire, T. J., and Quinn, S. 0., 1979, PCB in the upper Hudson River-mapping and sediment relationships: New York State Department of Environmental Conservation Technical Paper 56, 140 p.

Turk, J. T., 1980, Applications of Hudson River basin PCB-transport studies, in Baker, R. A., ed., Contaminants and sediments, volume 1: Ann Arbor, Mich., Ann Arbor Science Publishers, Inc., p. 171-183.

Turk, J. T., and Troutman, D. E., 1981a, Relationship of water quality of Hudson River, New York, during peak discharges to geologic characteristics of contributing subbasins: U.S. Geological Survey Water-Resources Investigations $80-108,15 \mathrm{p}$.

Turk, J. T., and Troutman, D. E., $1981 \mathrm{~b}$, Polychlorinated biphenyl transport in the Hudson River, New York: U.S Geological Survey Water-Resources Investigations $81-9,11 \mathrm{p}$.

U.S. Environmental Protection Agency, 1977, Quality criteria for water, 1976: Washington, D.C., 256 p.

U.S. Geological Survey, 1977-82, Water resources data for New York, water years 1976-81: Albany, N.Y., U.S. Geological Survey, Water data report, v. 1, New York excluding Long Is land. (Issued annually.) 